\title{
STUDI PERBANDINGAN PEMBELAJARAN KOOPERATIF TIPE THINK-PAIR- SHARE DENGAN TIPE TEAM GAMES TOURNAMENT TERHADAP HASIL BELAJAR MATEMATIKA BERDASARKAN WAKTU BELAJAR SISWA
}

\section{COMPARISON STUDY OF COOPERATIVE LEARNING BETWEEN THINK-PAIR- SHARE TYPE AND TEAM GAMES TOURNAMENT TYPE ON THE MATHEMATICS LEARNING OUTCOMES BASED ON STUDENT LEARNING TIME}

\author{
Nurhikmah'), Thamrin Tayeb ${ }^{2),}$ Ridwan Idris ${ }^{3)}$, Nidya Nina Ichiana ${ }^{4)}$, Sri Sulasteri ${ }^{5)}$ \\ $\mathbf{1 , 2 , 3 , 4 , 5 ) U n i v e r s i t a s ~ I s l a m ~ N e g e r i ~ A l a u d d i n ~ M a k a s s a r ~}$ \\ nurhikmah@gmail.com ${ }^{1}$, thamrin.tayeb@uin-alauddin.ac.id ${ }^{2}$, , ridwan.idris@uin-alauddin.ac.id ${ }^{3}$ ), \\ nidyanina.ichiana@uin-alauddin.ac.id ${ }^{4}$, sri.sulasteri@uin-alauddin.ac.id ${ }^{5}$ )
}

\begin{abstract}
Abstrak
Penelitian ini merupakan penelitian kuantitatif jenis experimental semu dengan nonequivalent control group design. Populasi penelitian ini adalah siswa kelas VIII MTs Negeri Balang-Balang. Sampel yang diperoleh menggunakan simple random sampling technique yakni 36 siswa untuk kelas eksperimen pagi, 35 siswa untuk kelas eksperimen siang, 36 siswa untuk kelas kontrol pagi, dan 36 siswa pada kelas kontrol siang. Instrumen yang digunakan adalah tes hasil belajar dan dokumentasi. Data dianalisis dengan teknik analisis statistik deskriptif dan inferensial dengan uji Anava 2 jalur. Berdasarkan analisis yang dilakukan pada data penelitian ini, diperoleh bahwa hasil belajar matematika siswa dengan menerapkan model pembelajaran kooperatif tipe Team Games Tournament yang ditinjau dari waktu belajar kelas eksperimen pagi dan siang diperoleh nilai rata-rata hasil belajar meningkat dari 51,73 menjadi 87,83 dan 48,3 menjadi 80,42 setelah diberikan posttest dengan peningkatan sebesar 36,1 dan 32,12, sedangkan hasil belajar matematika siswa dengan model pembelajaran kooperarif tipe Think Pair Share yang ditinjau dari waktu belajar pada kelas kontrol pagi dan siang diperoleh nilai rata-rata hasil belajar yang meningkat dari 52,67 menjadi 82,3 dan dari 47 menjadi 82,056 setelah diberikan posttest dengan peningkatan sebesar 29,63 dan 35,056. Selain itu, diperoleh bahwa rata-rata hasil belajar model pembelajaran kooperatif tipe TGT lebih baik daripada model pembelajaran kooperaatif tipe TPS berdasarkan waktu belajar.
\end{abstract}

Kata Kunci: model pembelajaran kooperatif tipe TGT dan TPS, hasil belajar, waktu belajar

\begin{abstract}
This research is a quasi-experimental quantitative research with a nonequivalent control group design. The population of this study were students of class VIII MTs Negeri BalangBalang. The sample was obtained using the simple random sampling technique, namely 36 students for the morning experiment class, 35 students for the afternoon experiment class, 36 students for the morning control class, and 36 students for the afternoon control class. The instrument used was a test of learning outcomes and documentation. Data were analyzed using descriptive and inferential statistical analysis techniques with the 2-way Anava test. Based on the analysis carried out on the data of this study, it was found that the results of students' mathematics learning by applying the Team Games Tournament type cooperative learning model in terms of learning time in the experimental class in the morning and afternoon obtained an average value of learning outcomes increased from 51.73 to 87.83 and 48.3 to 80.42 after being given a posttest with an increase of 36.1 and 32.12 , while the mathematics learning outcomes of students with the Think Pair Share cooperative learning
\end{abstract}


model in terms of learning time in the control class morning and afternoon obtained an average value of Average learning outcomes increased from 52.67 to 82.3 and from 47 to 82.056 after being given the posttest with increases of 29.63 and 35.056. In addition, it was found that the average learning outcomes of the TGT type of cooperative learning model were better than the TPS type of cooperative learning model based on learning time.

\section{Keywords: TGT and TPS cooperative learning, learning outcomes, learning time}

How to Cite: Nurhikmah, Tayeb, T., Idris, R., Ichiana, N.N., \& Sulasteri, S. (2021). Studi perbandingan pembelajaran kooperatif tipe think-pair-share dengan tipe team games tournament terhadap hasil belajar matematika berdasarkan waktu belajar siswa. Al asma: Journal of Islamic Educationn, 3(1), 73-84.

\section{PENDAHULUAN}

Manusia mempunyai potensi kecerdasan intelektual, emosional, dan spiritual. Melalui pendidikan, manusia mampu berkembang secara bertahap demi mencapai level tertentu berdasarkan potensi kemanusian melalui pendidikan. Pendidikan lebih dari pengajaran dalam kenyataannya. Pendidikan adalah usaha atau kegiatan manusia untuk membina kepribadiannya sesuai dengan nilai-nilai di dalam masyarakat dan kebudayaan.

Pendidikan menjadi kebutuhan dasar yang harus dipenuhi untuk kehidupan sehari-hari bagi setiap individu, karena pendidikan dapat menghasilkan generasi yang lebih baik, terampil, dan handal dalam bidang yang mereka kuasai (Ahmadi, 2014). Pendidikan dapat menciptakan generasi yang unggul dan berdaya saing dalam menghadapi tantangan yang akan terjadi dimasa yang akan datang (Fauzi, Erna, \& Linda, 2021). Jadi, pendidikan adalah suatu proses yang terjadi secara bertahap yang dapat meningkatkan kecerdasan dan keterampilan individu melalui proses belajar.

Proses belajar mampu berlangsung kapan saja dan dimana saja, terlepas dari adanya yang mengajar atau tidak. Hal ini bisa terwujud jika terdapat interaksi antarindividu di lingkungan tersebut. Proses belajar menjadi kegiatan inti dalam melestarikan pendidikan dan guru mempunyai peran penting dalam hal tersebut. Seorang guru tak hanya dituntut untuk mentransfer pengetahuan dan pengalamannya ke dalam proses mengajar, namun guru dapat memberikan inspirasi kepada siswa untuk mengembangkan potensi dan kualitasnya. Belajar merupakan hubungan timbal balik antara individu dengan individu lainnya, antara individu dengan kelompok, serta kelompok dengan kelompok lainnya. Secara sosiologi, pembelajaran yang menganut kontruktivisme menekankan pada pentingya lingkungan sosial dalam belajar dengan menyatakan bahwa integritasi kemampuan dalam belajar kolaboratif dan kooperatif akan dapat meningkatkan pengubahan secara konseptual.

Matematika menempati peringkat yang menonjol di antara cabang-cabang ilmu pengetahuan dan merupakan pilar semua ilmu bergantung, memainkan peran penting dalam kebangkitan bangsa, memiliki peran penting dalam kemajuan, pertumbuhan, dan kemakmuran peradaban sebelumnya dan di era saat ini (Farrajallah, 2017). Dalam pembelajaran matematika dipelajari berbagai materi yang memiliki konsep yang memerlukan kolaborasi dan kerja sama antar siswa, sehingga siswa dapat menyelesaikan materi-materi tersebut dengan baik. Pembelajaran ini akan dikatakan berhasil apabila seluruh siswa terlibat aktif dalam pembelajaran, pembelajaran yang dimaksud adalah 
sebuah pembelajaran kooperatif yang menuntut siswa untuk bekerjasama dengan baik di kelompok yang dipimpin dan diarahkan langsung oleh guru yang bersangkutan. Dalam pembelajaran kooperatif ini guru membuat permasalahan-permasalahan dan menyajikan informasi yang dibutuhkan oleh siswa dalam mengerjakan masalah tersebut.

Salah satu alternatif dalam memecahkan persoalan pada pembelajaran matematika adalah mengaplikasikan suatu model pembelajaran. Banyak jenis model yang dapat diterapkan yang memiliki karakteristik, kelebihan dan kekurangan masing-masing (Dianti, Agustini, \& Sugihartini, 2016). Pembelajaran kooperatif ada beberapa tipe yang bisa diaplikasikan dalam proses belajar, misalnya Think Pair Share (TPS) dan Team Games Tournament (TGT) yang menekankan pada penggunaan struktur tertentu dan berakibat pada pola interaksi yang dihasilkan siswa saat proses pembelajaran.

Munculnya model pembelajaran Think Pair Share (TPS) berawal dari suatu konsep bahwa siswa lebih antusias dalam menemukan dan memahami suatu konsep jika berdiskusi antarsiswa. Model ini merupakan suatu cara yang efektif dalam menghidupkan diskusi kelompok dalam kelas, karena dapat memberikan tanggung jawab individu dan kelompok kepada siswa, serta siswa diberi waktu yang lebih banyak untuk berpikir dan memberikan respon, sehingga memunculkan partisipasi siswa. Pelaksanaan model TPS memiliki 3 tahap yaitu think (berpikir), pair (berpasangan), dan share (berbagi) (Ganatra et al., 2020; Sumekto, 2018). Biasanya, guru mengajukan pertanyaan, siswa menulis tentang topik (think), kemudian berpasangan untuk mendiskusikan jawaban mereka (pair), kemudian mempresentasikan jawaban mereka di depan kelas (share) (Cooper, 2018). Hal ini juga sesuai dengan pengertian model pembelajaran kooperatif tipe TPS yang dikemukakan oleh Lie dalam Dianti, Agustini, \& Sugihartini (2016) bahwa pembelajaran memberi siswa kesempatan untuk bekerja sendiri dan bekerjasama dengan orang lain. Dari uraian tersebut, dapat disimpulkan bahwa model TPS adalah pembelajaran kelompok yang membantu dan memberi kesempatan kepada siswa untuk berpikir mandiri dan saling membantu dengan teman kelompoknya.

Model pembelajaran tipe Think Pair and Share (TPS) memiliki struktur khusus yang dipersiapkan untuk memberikan pengaruh pada pola interaksi siswa dalam bekerja bersama, melengkapi, dan saling ketergantungan dalam kelompok belajar dalam proses pembelajaran (Barokah \& Raharja, 2021). Model pembelajaran Think Pair Share (TPS) juga memperkenalkan ide "waktu berpikir" sebagai faktor terkuat dalam menambah kualitas kemampuan siswa saat merespon pertanyaan. Waktu dan tempat yang digunakan dalam melaksanakan model ini tidak terlalu lama sehingga lebih mudah untuk mengatur siswa dalam pengelompokan (Sinaga \& Rajagukguk, 2018). Model Think Pair Share (TPS) memberikan siswa kebebasan untuk mengekspresikan pandangan mereka tanpa rasa takut atau ragu-ragu (Fitriani, Baharuddin, \& Kayanti, 2019; Hamdan, 2017). Pada model ini, keterlibatan dan pemahaman siswa dapat meningkat (Prahl, 2017). Model ini juga berperan dalam meningkatkan keterampilan komunikasi lisan dan motivasi siswa (Raba, 2017).

Model pembelajaran kooperatif tipe Teams Games Tournament (TGT) merupakan salah satu model pembelajaran kooperatif yang tidak membedakan status sosial siswa, serta melibatkan siswa sebagai tutor sebaya serta mengandung unsur-unsur permainan dan reinforcement. Dalam pelaksanaan model ini, siswa dituntut untuk mengembangkan karakternya, terutama displin, bekerja keras, berpikir kritis, logis dan kreatif. TGT 
menitikberatkan pada aktivitas siswa yang juga terdapat permainan di dalamnya, sehingga siswa tidak heran bila dapat mengurangi kebosanan siswa dalam mengikuti proses pembelajaran (Azizah, Nengsih, Wati \& Nastiti, 2021). Hal ini juga membuat siswa dapat belajar lebih rileks, sehingga lebih mudah dalam memahami materi pelajaran yang diberikan. Pada model TGT, siswa memainkan sebuah game dengan kelompok lain untuk mendapatkan poin, permainan ini berupa soal-soal yang relevan dengan materi yang sementara berlangsung untuk melihat pengetahuan mereka tentang materi tersebut. Permainan ini dimainkan pada sebuah meja tournament yang telah disiapkan dan setiap meja tournament diwakili oleh 1 orang dari setiap kelompok. Dengan menerapkan model pembelajaran TGT, siswa diharapkan lebih bersemangat karena adanya game dalam pembelajaran di kelas dan dimana pemenang dalam game ini akan diberikan suatu penghargaan sehingga siswa lebih termotivasi dalam belajar (Hikmah, Anwar, \& Riyato, 2018). TGT (Team Games Tournament) dapat meningkatkan partisipasi siswa dalam berbicara. Situasi kooperatif di TGT memacu siswa untuk memberikan kontribusi dan kerjasama yang baik dalam pembelajaran (Intan \& Wahyuni, 2014).

Menurut Taniredja dalam Mugas (2014) terdapat beberapa kelebihan dari pembelajaran kooperatif tipe TGT (Team Games Tournament) yaitu siswa mempunyai kebebasan untuk berinteraksi dan mengajukan pendapatnya, menjadi lebih percaya diri, kecilnya peluang siswa mengganggu siswa lain, bertambahnya motivasi siswa, pemahaman terhadap pokok bahasan menjadi lebih mendalam, dan meningkatkan kebaikan budi, kepekaan, dan toleransi antarsiswa dan antara siswa dengan guru, serta siswa bebas mengaktualisasikan diri dengan seluruh potensinya.

Kedua model pembelajaran ini baik digunakan dalam konsep perhitungan dan untuk mendapatkan hasil belajar yang lebih baik, serta mendapatkan nilai standar ketuntasan mereka secara keseluruhan tanpa adanya perbedaan dari hasil belajar. Adapun penelitian yang dilakukan oleh Handoko (2013) menyatakan bahwa hasil belajar siswa yang menggunakan model Team Games Tournament (TGT) mengalami peningkatan. Hasil penelitian yang dilakukan oleh Kusmiati, Chamdani, \& Suryandari, (2016) bahwa hasil belajar siswa yang menggunakan model pembelajaran Think Pair Share (TPS) mengalami peningkatan. Sejalan dengan hal tersebut, penelitian yang dilakukan Nasution \& Surya (2017) juga menunjukkan bahwa terjadi peningkatan hasil belajar siswa setelah menerapkan model pembelajaran Think Pair Share (TPS). Oleh karena itu, penelitian ini bertujuan untuk melakukan studi perbandingan pembelajaran kooperatif tipe think-pairshare dengan tipe team games tournament terhadap hasil belajar matematika berdasarkan waktu belajar siswa kelas VIII MTs Negeri Balang-Balang.

\section{METODE PENELITIAN}

Jenis penelitian merupakan penelitian ekperimen semu. Penelitian ini bertujuan untuk mengetahui ada tidaknya pengaruh terhadap variabel yang diberikan perlakuan model kooperatif tipe Think Pair Share (TPS) dan model kooperatif tipe Team Games Tournament (TGT). Desain penelitian yang digunakan adalah nonequevalent control grup design dimana desain ini terdapat empat kelompok yang telah dipilih kemudian diberi pretest dan posttest.

Penelitian ini dilaksanakan di kelas VIII MTs Negeri Balang-Balang. Populasi dalam penelitian ini berjumlah 213 siswa. Teknik pengambilan sampel menggunakan simple 
random sampling dan jumlah sampel yang diambil sebanyak 143 orang siswa, yakni 36 siswa untuk kelas eksperimen pagi, 35 siswa untuk kelas eksperimen siang, 36 siswa untuk kelas kontrol pagi, dan 36 siswa pada kelas kontrol siang. Pengumpulan data dilakukan dengan menggunakan instrumen tes hasil belajar dan dokumentasi. Data yang dihasilkan merupakan data hasil pengamatan dan tanggapan guru matematika disekolah tempat penelitian dianalisis secara kualitatif, sedangkan data hasil belajar dianalisis menggunakan analisis statistik deskriptif dan statistik inferensial.

\section{HASIL DAN PEMBAHASAN}

1. Deskripsi Hasil Belajar Matematika yang Menerapkan Model Pembelajaran Koperatif Tipe Team Games Tournament berdasarkan Waktu Belajar Siswa

Berdasarkan hasil pretest dan posttest yang dilakukan oleh siswa kelas eksperimen didapatkan bahwa hasil dari analisis data yang diperoleh dari hasil pretest dan posttest kelas eksperimen model kooperatif tipe Team Games Tournament diperoleh seperti data dibawah ini:

Tabel 1. Deskripsi Hasil Belajar Matematika dengan Model Pembelajaran Kooperatif Tipe Team Games Tournament

\begin{tabular}{ccccc}
\hline \multirow{2}{*}{ Statistik } & \multicolumn{4}{c}{ Nilai Statistik Siswa } \\
\cline { 2 - 5 } & $\begin{array}{c}\text { Pretest } \\
\text { Pagi }\end{array}$ & $\begin{array}{c}\text { Posttest } \\
\text { Pagi }\end{array}$ & $\begin{array}{c}\text { Pretest } \\
\text { Siang }\end{array}$ & $\begin{array}{c}\text { Posttest } \\
\text { Siang }\end{array}$ \\
\hline Jumlah Sampel & 36 & 36 & 39 & 35 \\
Nilai Tertinggi & 65 & 97 & 67 & 90 \\
Nilai Terendah & 36 & 73 & 27 & 60 \\
\hline
\end{tabular}

Diperoleh dari tabel statistik untuk kelas eksperimen model kooperatif tipe Team games tournament untuk data pretest dan posttest di pagi hari terlihat jika nilai terendah 36 dan nilai tertinggi 73 , dan nilai posttest berada pada nilai 73 dan yang paling tinggi adalah 97. Sedangkan untuk kelas siang pretest berada pada nilai terendah yaitu 27 dan tertinggi 67, nilai posttest nilai terendah itu 60 dan yang tertinggi 90.

2. Deskripsi Hasil Belajar Matematika yang Menerapakan Model Pembelajaran Kooperatif Tipe Think Pair Share berdasarkan Waktu Belajar Siswa

Dalam hasil perhitungan data penelitian yang didapatkan dari pretest dan posttest pada kelas kontrol model kooperatif tipe Think Pair Share diperoleh:

Tabel 2. Deskripsi Hasil Belajar Matematika dengan Model Pembelajaran Kooperatif Tipe Think Pair Share

\begin{tabular}{ccccc}
\hline \multirow{2}{*}{ Statistik } & \multicolumn{4}{c}{ Nilai Statistik Siswa } \\
\cline { 2 - 5 } & $\begin{array}{c}\text { Pretest } \\
\text { Pagi }\end{array}$ & $\begin{array}{c}\text { Posttest } \\
\text { Pagi }\end{array}$ & $\begin{array}{c}\text { Pretest } \\
\text { Siang }\end{array}$ & $\begin{array}{c}\text { Posttest } \\
\text { Siang }\end{array}$ \\
\hline Jumlah Sampel & 36 & 36 & 36 & 36 \\
Nilai Tertinggi & 63 & 91 & 56 & 91 \\
Nilai Terendah & 34 & 72 & 35 & 65 \\
\hline
\end{tabular}

Dari tabel diatas terlihat jika pada pretest dan posttest di pagi hari terdapat peningkatan ini terlihat dari pretest nilai terendah 34 menjadi 63 pada nilai tertingginya, untuk posttest sebesar nilai terendah 71 menjadi 91. Demikian juga terjadi pada pretest dan posttes pada siang hari juga terjadi peningkatan dimana nilai terendah sebelum 
diberikan perlakuan itu sebesar 35 dan 56 untuk nilai tertingginya, sedangkan untuk nilai setelah diberi di perlakuan nilai terendah sebesar 65 daan nilai tertinggi sebesar 91 .

3. Perbedaan Hasil Belajar Matematika yang Menerapkan Model Pembelajaran Kooperatif Tipe Team Games Tournament dan Model Kooperatif Tipe Think Pair Share berdasarkan Waktu Belajar Siswa

Untuk membahas pada bagian ini yaitu dengan menggunakan statistik inferensial. Dalam melakukan analisis inferensial, perlu dilakukan uji prasyarat terlebih dahulu, seperti pengujian normalitas dan uji homogenitas. Hal ini dilakukan untuk mengetahui terdapat atau tidak perbedaan signifikan hasil belajar siswa yang belajar dengan model pembelajaran kooperatif tipe Team Games Tournament (TGT) dan Think Pair Share (TPS) yang ditinjau dari waktu belajar siswa.

a. Uji Normalitas

Data hasil penelitian pretest dan posttest pada kelas eksperimen dan kontrol dilakukan uji normalitas. Uji normalitas menggunakan rumus Kolmograf-Smirnov. Dinyatakan memenuhi kriteria pengujian normal bila sign $>0,05$ dan $d k=(k-1)$ pada taraf signifikan $\alpha=0,05$

1) Kelas Eksperimen Pagi dan Siang

Pada hasil pretest dan posttest kelas eksperimen pagi dan siang, taraf signifikan uji normalitas yang digunakan yaitu 0,05 dengan derajat kebebasan $(\mathrm{dk})=\mathrm{k}-1$.

Tabel 3. Uji Normalitas Hasil Pretest dan Posttest Kelas Eksperimen Pagi dan siang

\begin{tabular}{|c|c|c|c|c|c|}
\hline & & $\begin{array}{c}\text { Pretest } \\
\text { Kelas } \\
\text { Eksperimen } \\
\text { Pagi }\end{array}$ & $\begin{array}{c}\text { Posttest } \\
\text { Kelas } \\
\text { Eksperimen } \\
\text { Pagi }\end{array}$ & $\begin{array}{c}\text { Pretest } \\
\text { Kelas } \\
\text { Eksperimen } \\
\text { Siang }\end{array}$ & $\begin{array}{c}\text { Posttest } \\
\text { Kelas } \\
\text { Eksperimen } \\
\text { Siang }\end{array}$ \\
\hline \multirow[t]{2}{*}{$N$} & & 36 & 36 & 35 & 35 \\
\hline & Mean & 51.6667 & 88.0556 & 47.9143 & 80.6857 \\
\hline Normal & Std. & & & & \\
\hline \multirow{2}{*}{ Parameters $a, b$} & Deviation & 7.16739 & 5.64140 & 8.13985 & 8.13045 \\
\hline & Absolute & .102 & .135 & .121 & .102 \\
\hline \multirow{2}{*}{$\begin{array}{c}\text { Most Extreme } \\
\text { Differences }\end{array}$} & Positive & .070 & .062 & .079 & .069 \\
\hline & Negative & -.102 & -.135 & -.121 & -.102 \\
\hline $\begin{array}{l}\text { Kolmogorov- } \\
\text { Smirnov Z }\end{array}$ & & .611 & .809 & .714 & .601 \\
\hline $\begin{array}{c}\text { Asymp. Sig. (2- } \\
\text { tailed) }\end{array}$ & & .849 & .530 & .688 & .863 \\
\hline
\end{tabular}

Dari tabel diatas, dapat dilihat bahwa hasil Kolmogorov-Smirnov Z pada kelas eksperimen pagi sebesar 0,611 dan sig. p-value $=0,849>0,05$. Nilai statistik eksperimen siang itu terlihat bahwa Kolmogorov-Smirnov Z sebesar 0,714 dan sign p-value $=0,688>$ 0,05 pada taraf signifikan $\alpha=0,05$, sehingga dapat dinyatakan bahwa data berdistribusi normal.

2) Kelas Kontrol Pagi dan Siang

Taraf signifikan uji normalitas yang dilakukan di kelas kontrol pagi dan siang yaitu 0,05 . Selain itu, derajat kebebasan yang dipakai adalah $\mathrm{dk}=\mathrm{k}-1$. 
Tabel 4. Uji Normalitas Hasil Pretest dan Posttest Kelas Kontrol pagi dan Siang

\begin{tabular}{llrrrr}
\hline & & $\begin{array}{c}\text { Pretest } \\
\text { Kelas } \\
\text { Kontrol } \\
\text { Pagi }\end{array}$ & $\begin{array}{c}\text { Posttest } \\
\text { Kelas } \\
\text { Kontrol } \\
\text { Pagi }\end{array}$ & $\begin{array}{c}\text { Pretest } \\
\text { Kelas } \\
\text { Kontrol } \\
\text { Siang }\end{array}$ & $\begin{array}{c}\text { Posttest } \\
\text { Kelas } \\
\text { Kontrol } \\
\text { Siang }\end{array}$ \\
\hline$N$ & Mean & 52.5556 & 82.2500 & 47.1111 & 81.9167 \\
Normal & Std. & & & & 36 \\
Parameters, $b$ & Deviation & 7.33463 & 6.03502 & 5.84455 & 6.39810 \\
& Absolute & .109 & .105 & .127 & .127 \\
Most Extreme & Positive & .077 & .100 & .092 & .078 \\
Differences & & & & & \\
Kolmogorov- & Negative & -.109 & -.105 & -.127 & -.127 \\
$\begin{array}{l}\text { Smirnov Z } \\
\text { Asymp. Sig. }(2-\end{array}$ & & .652 & .630 & .760 & .763 \\
tailed) & & .789 & .822 & .610 & .605 \\
\hline
\end{tabular}

Dari tabel diatas dapat dilihat bahwa nilai statistik pretest kelas kontol pagi untuk Kolgomorov-Smirnov Z sebesar 0,652 dan hasil p-value $=0,789>0,05$, sedangkan untuk kelas kontrol siang Kolmogorov-Smirnov Z sebesar 0,760 dan p-value $=0,610>0,05$ sehingga data tersebut dapat dikatakan berdistribusi normal. Pada tabel juga terlihat bahwa hasil posttest kelas kontrol pagi dengan Kolgomorov-Smirnov Z sebesar 0,630 dan $\mathrm{p}$-value $=0,822>0,05$, hasil posttest untuk kelas kontrol siang kolgomorov-Smirnov $\mathrm{Z}$ sebesar 0,763 dan hasil p-value $=0,605>0,05$. Hal ini dapat dikatakan bahwa dari penelitian diatas menggunakan taraf signifikan $\alpha=0,05$, maka data berdistribusi normal.

Jadi, diperoleh bahwa data hasil pretest dan posttest kelas kontrol dan kelas ekperimen berdistribusi normal.

b. Uji Homogenitas

Uji homogenitas hanya menggunakan hasil posttest. Hal ini dilakukan karena hanya ingin mencari kesamaan hasil belajar yang diberikan kepada keempat kelas yang telah diberikan perlakuan dengan model pembelajaran yang berbeda yaitu model pembelajaran Team Games Tornoument dan Think Pair Share, dengan taraf signifikan yang sudah ditetapkan sebelumnya adalah $\alpha=0,05$.

Pengujian homogenitas dapat dilakukan jika ingin mengetahui sampel yang diperoleh berasal dari populasi yang sama atau tidak. Hal ini dapat dilakukan dengan melihat varians dari kelompok sampel sama atau tidak. Sata yang diujji dinyatakan homogen, jika sign $>\alpha=0,05$.

Tabel 5. Hasil Belajar Matematika

\begin{tabular}{cccc}
\hline Levene Statistik & $\boldsymbol{d} \boldsymbol{f 1}$ & $\boldsymbol{d} \boldsymbol{f 2}$ & Sig. \\
\hline 1,558 & 3 & 139 & 0,202 \\
\hline
\end{tabular}

Tabel 5 menunjukkan bahwa nilai sig. $=0,202$ data hasil posttest dari keempat kelas tersebut homogen karena nilai sig. lebih besar dari nilai $\alpha(0,202>0,05)$. Prasyarat uji normalitas dan uji homogenitas untuk statistik parametrik terpenuhi, sehingga statistik inferensial dapat dilakukan.

Uji hipotesis dapat dilakukan pada posttest keempat kelas karena telah memenuhi syarat untuk statistik parametrik. Uji hipotesis ini memakai uji ANAVA 2 jalur. Uji 
hipotesis dilakukan untuk mengetahui dugaan sementara dengan menggunakan aplikasi SPSS.

Tabel 6. Hasil Uji ANAVA 2 Jalur

\begin{tabular}{lrrrrc}
\hline \multicolumn{1}{c}{ Source } & Type III Sum of Square & Df & Means Square & \multicolumn{1}{c}{ F } & Sig. \\
\hline Corrected Model & $1161,502^{\mathrm{a}}$ & 3 & 387,167 & 8,867 & 0,000 \\
Intercept & 990375,140 & 1 & 990375,140 & 22683,093 & 0,000 \\
A & 187,007 & 1 & 187,007 & 4,283 & 0,040 \\
B & 530,263 & 1 & 530,263 & 12,145 & 0,001 \\
$A^{*} B$ & 442,452 & 1 & 442,452 & 10,134 & 0,002 \\
Error & 6068,932 & 139 & 43,661 & & \\
Total & 998176,000 & 143 & & & \\
Corrected Total & 7230,434 & 142 & & & \\
\hline
\end{tabular}

Berdasarkan hasil pengelohan data dengan menggunakan SPSS, diperoleh:

1. $\mathrm{Fo}_{\mathrm{O}}(\mathrm{A})=4,283$ dengan $\mathrm{p}$-value $=0,040<0,05$ atau $\mathrm{H}_{0}$ ditolak. Ini menunjukkan terdapat perbedaan rata-rata hasil belajar matematika antara siawa yang diajar dengan menggunakan model pembelajaran kooperatif tipe Team Games Tournament dan model pembelajaran kooperatif tipe Think Pair Share.

2. $\mathrm{Fo}_{\mathrm{O}}(\mathrm{B})=12,145$ dengan $\mathrm{p}$ Value $=0,001<0,05$ atau $\mathrm{H}_{0}$ ditolak. Ini berarti terdapat perbedaan rata-rata hasil belajar matematika antara siswa yang belajar pagi dan siang

3. $\mathrm{F}_{\mathrm{O}}(\mathrm{B})=10,134$ dengan $\mathrm{p}$-Value $=0,002<0,05$ atau $\mathrm{H}_{0}$ ditolak. Ini menunjukkan bahwa terdapat pengaruh interaksi yang signifikan antara model pembelajaran dan waktu belajar terhadap hasil belajar.

Dari ketiga pernyataan di atas, dapat disimpulkan bahwa terdapat perbedaan hasil rata-rata belajar matematika siawa dengan menerapkan model pembelajaran kooperatif tipe Team Games Tournament dan model pembelajaran kooperatif tipe Think Pair Share di tinjau dari waktu belajar siswa.

Pretest ialah hasil belajar siswa pada mata pelajaran matematika sebelum diadakannya perlakuan pada masing-masing kelompok sedangkan posttest ialah hasil belajar setelah kedua kelompok diberikan perlakuan. Dari hasil penelitian yang telah dilakukan terlihat bahwa rata-rata hasil belajar matematika siswa pada kelas eksperimen pagi dan siang sebelum menggunakan model pembelajaran kooperatif tipe Team Games Tournament dimana hasil belajar siswa di pagi hari sebelum diberi perlakuan sebesar 51,73 dengan standar deviasi sebesar 7,2086 dan pada siang hari sebesaar 48,3 dengan standar deviasi 8,0761. Sementara untuk rata-rata hasil belajar siswa setelah menggunakan model pembelajaran kooperatif tipe Team Games Tournament pada kelas eksperimen dimana hasil belajar siswa dipagi hari sebesar 87,83 dengan standar deviasi 5,7370 dan kelas eksperimen siang sebesar 80,42 dengan standar deviasi 7, 9035. Dari data tersebut terlihat bahwa terjadi peningkatan hasil belajar matematika siswa sebelum dan setelah diberi perlakuan model kooperatif tipe Team Games Tournament yaitu dengan selisih 36,1 pada pagi hari dan padda siang hari yaitu selisih 32,12. Hal ini menunjukkkan bahwa model kooperatif tipe Team Games Tournament berpengaruh terhadap mtematika siswa dikelas pagi, dan berdasarkan observasi pada saat pembelajaran siswa focus memperhatikan pembelajaran dimana setiap pertemuan siswa aktif bertanya maupun dalam membahas soal-soal yang ada. Berbeda dengan kelas siang dimana siswa kurang focus memperhatikan pembelajaran. 
Rata-rata hasil belajar matematika pada kelas kontrol pagi dan siang sebelum diberi perlakuan model pembelajaran kooperatif tipe Think Pair Share pada pagi hari hasil belajar yang didapat sebesar 52,67 dengan standar deviasi sebesar 7, 1713 sedangkan pada siang hari hasil belajar yang didapat sebesar 47 dengan standar deviasi sebesar 5,8700. Untuk rata-rata hasil belajar matematika setelah diberi perlakuan model pembelajaran kooperatif tipe Thik Pair Share pada pagi hari sebesar 82,3 dengan standar deviasi 6,1155 dan untuk model pembelajaran kooperatif tipe Think Pair Share pada siang hari memiliki rata-rata sebesar 82,056 dengan standar deviasi sebesar 6,509. Dari hasil yang diperoleh terjadi peningkatan hasil matematika siswa sebelum dan sesudah menggunakan model pembelajaran kooperatif tipe Think Pair Share dengan selisih pagi hari sebesar 29,63 dan pada siaang siang hari sebesar 35,056. Ini menunjukkan bahwa model pembelajaran kooperatif tipe Think Pair Share juga berpengaruh dalam meningkatkan hasil belajar matematika siswa pada kelas pagi dan siang, sesuai hasil observasi pada saat pembelajaran dipagi hari didapatkan bahwa hampir semua siswa fokus dan memperhatikan pembelajaran karena dalam setiap pertemuan siswa sudah lebih aktif dalam pembelajaran tetapi berbeda dengan siswa yang belajar di siang hari dimana masih banyak siswa yang kurang memperhatikan materi pada saat pembelajaran. Dari pembahasan dia atas dapat disimpulkan bahwa model pembelajaran kooperatif tipe kooperatif tipe Team Games Tournament dan model kooperatif tipe Think Pair Share dapat meningkatkan hasil belajar matematika siswa dari keempat kelas tersebut.

Selanjutnya untuk mengetahui bagaimana perbandingan hasil belajar matematika siswa yang ditinjau dari waktu belajar maka terlebih dahulu harus melakukan uji normalitas, uji homogenitas, dan uji hipotesis dimana pada penelitian ini menggunakan uji Anava 2 jalur. Hasil analisis data yang telah dilakukan dengan menggunakan SPSS Versi 20 diperoleh bahwa hasil belajar siswa dari keempat kelas untuk pretest dikelas eksperimen pagi hasil Kormogorov-Sminov memiliki p-Value $=0,849>0,05$ dan eksperimen siang hasil Kormogorov-Sminov memiliki p-Value $=0,688>0,05$ dengan taraf sigfinikan $\alpha=$ 0,05 . Sedangkan untuk posttest kelas eksperimen pagi hasil Kormogorov-Sminov memiliki $p$-Value $=0,530>0,05$ dan kelas eksperimen siang hasil Kormogorov -Sminov memiliki pValue $=0,863>0,05$ dengan taraf signifikan $\alpha=0,05$. Maka dapat dikatakan bahwa kelas eksperimen pagi dan siang berdistribusi normal. Sedangkan untuk kelas kontrol pagi untuk hasil pretest menunjukkan bahwa Kormogorov-Sminov memiliki p-Value $=0,789>$ 0,05 dan pretest kelas kontrol siang hari menunjukkan bahwa Kormogorov-Sminov memiliki p-Value $=0,610>0,05$ dengan taraf signifikan $\alpha=0,05$. Untuk hasil posttest kelas kontrol pagi menunjukkan bahwa hasil Kormogorov-Sminov memiliki p-Value $=$ 0,822 > 0,05 dan kontrol siang menunjukkan bahwa Kormoogorov-Sminov memiliki pValue $=0,605>0,05$ dengan taraf signifakan sebesar $\alpha=0,05$. Maka dapat simpulkan kelas eksperimen kontrol pagi dan siang hari berdistribusi normal.setelah menentukan hasil uji normalitas data maka dilanjutkan dengan menentukan hasil pengujian homogenitas yang menggunakan nilai posstest yang didapat dari keempat kelas dan menunjukkan bahwa nilai sign $>\alpha=0,202>0,05$. Dengan menunjukkan bahwa penelitian ini menunjukkan bahwa keempat data tersebut homogen. Pengujian hipotesis dengan uji Anava 2 jalur dimana hasil pengolahan data yang telah dilakukan diperoleh $\mathrm{F} 0(\mathrm{AB})=10,134$ dengan $\mathrm{p}$ Value $=0,002<0,05$ atau $\mathrm{H}_{0}$ ditolak, yang artinya terdapat pengaruh interaksi yang signifikan antara model pembelajaran dan waktu belajar terhadap hasil belajar. 
Sejalan dengan hasil penelitian Sinaga \& Rajagukguk (2018) yang mengggambarkan bahwa terdapat perbedaan hasil belajar siswa yang diajar menggunakan model pembelajaran kooperatif tipe Teams Games Tournament dengan model pembelajaran kooperatif tipe Think Pair Share di Kelas VIII SMPN 2 Kotapinang dan hasil belajar siswa dengan menggunakan model pembelajaran kooperatif tipe Teams Games Tournament lebih tinggi dari hasil belajar siswa yang diajarkan dengan model pembelajaran kooperatif tipe Think Pair Share dikelas VIII SMPN 2 Kotapinang. Begitu pula penelitian yang dilakukan oleh Salam (2014) menyatakan bahwa kemampuan komunikasi matematika siswa yang diajarkan dengan menggunakan model pembelajaran kooperatif tipe Think Pair Share lebih signifikan daripada model pembelajaran konvensional. Penerapan model pembelajaran TGT dimana penelitian yang dilakukan oleh Awofala, Fatade, \& Ola-Oluwa (2012) menunjukkan perbedaan yang signifikan dari prestasi belajar matematika siswa antara pembelajaran kooperatif dan pembelajaran individu. Model cooperative ini dapat meningkatkan penguasaan materi siswa dari konten matematika baik di tingkat pemahaman dan aplikasi.

Dengan demikian dapat disimpulkan bahwa terdapat perbedaan rata-rata hasil belajar matematika siswa dengan menerapkan dengan model pembelajaran kooperatif tipe Team Games Tournament dan model kooperatif tipe Think Pair Share ditinjau dari waktu belajar siswa, ini berarti terdapat perbedaan rata-rata antara hail belajar model pembelajaran dan waktu belajar. Berdasarkan waktu belajar, rata-rata hasil belajar lebih baik jika di pagi hari karena kondisi dan suasana dipagi hari yang lebih segar, dan sejuk sehingga siswa lebih efektif dan bersemangat dalam menerima setiap pembelajaran, berbeda pada siang hari yang suasana panas, badan letih, memori kerja otak juga sudah menurun karena berbagai pembelajaran yang telah didapatkan sebelumnya sehingga pembelajaran kurang efektif dalam menerima pembelajaran matematika.

\section{SIMPULAN}

Hasil belajar matematika siswa dengan menerapkan model pembelajaran kooperatif tipe Team Games Tournament yang ditinjau dari waktu belajar kelas eksperimen pagi dan siang diperoleh nilai rata-rata hasil belajar meningkat dari 51,73 menjadi 87,83 dan 48,3 menjadi 80,42 setelah diberikan posttest dengan peningkatan sebesar 36,1 dan 32,12, sedangkan hasil belajar matematika siswa dengan model pembelajaran kooperarif tipe Think Pair Share yang ditinjau dari waktu belajar pada kelas kontrol pagi dan siang diperoleh nilai rata-rata hasil belajar yang meningkat dari 52,67 menjadi 82,3 dan dari 47 menjadi 82,056 setelah diberikan posttest dengan peningkatan sebesar 29,63 dan 35,056. Berdasarkan hasil yang diperoleh terlihat bahwa hasil belajar siswa di kelas eksperimen mengalami peningkatan lebih tinggi dibandingkan dengan kelas kontrol. Berdasarkan perhitungan uji hipotesis menggunakan Anava 2 jalur diperoleh sign $>\alpha(0,002<0,05)$ maka $\mathrm{H}_{0}$ ditolak dan $\mathrm{H}_{1}$ diterima, sehingga penggunaan model pembelajaran ditinjau dari waktu belajar lebih efektif dalam meningkatkan hasil belajar matematika siswa. Hal itu ditunjukkan nilai rata-rata posttest yang diperoleh keempat kelas yaitu kelas ekperimen pagi dan siang yaitu 87,83 dan 80,42, sedangkan kelas kontrol pagi dan siang sebesar 82,3 dan 82,056, dengan kata lain model pembelajaran yang ditinjau dari waktu belajar mempunyai perbedaan terhadap hasil belajar matematika siswa. 


\section{DAFTAR PUSTAKA}

Ahmadi, R. (2014). Pengantar pendidikan asas dan filsafat pendidikan. Ar-Ruzz Media.

Awofala, A. O. A., Fatade, A. 0., \& Ola-Oluwa, S. A. (2012). Achievement in cooperative versus individualistic goal-structured Junior secondary school mathematics classrooms in Nigeria. International Journal of Mathematics Trends and Technology, 3(1), 7-12. http://ijmttjournal.org/Volume-3/issue-1/IJMTT-V3I1P502.pdf.

Azizah, N., Nengsih, E. W., Wati, L., \& Nastiti, L. R. (2021). The perspective on monopoly as media in physics learning by using Teams Games Tournament. Physics Education Journal of Physics: Conference Series, 1760(12015), 1-7. https://doi.org/10.1088/1742-6596/1760/1/012015.

Barokah, A. R., \& Raharja, S. (2021). Improving learning motivation and the ability to organism categorize with Think Pair Share learning model. Proceedings of the 6th International Seminar on Science Education (ISSE 2020), 541, 845-852. https://doi.org/10.2991/assehr.k.210326.122.

Cooper, F. (2018). A modification of think pair share to make it more learner-centered by using student-generated questions. College Teaching, 66(1), 34. https://doi.org/10.1080/87567555.2017.1390438.

Dianti, N. P. S., Agustini, K., \& Sugihartini, N. (2016). Studi komparatif penggunaan model pembelajaran Think Pair Share dan Teams Games Tournament terhadap motivasi dan hasil belajar TIK siswa kelas VIII SMPN 1 Sawan Tahun Ajaran 2015/2016. Kumpulan Artikel Mahasiswa Pendidikan Teknik Informatika (KARMAPATI), 5(2), 112. http://dx.doi.org/10.23887/karmapati.v5i2.8214.

Farrajallah, A. E.-K. (2017). The impact of employing the (Think-Pair-Share) strategy to gain some number sense skills and mathematical communication skills among fifth grade students. In An-Najah University Journal for Research - B (Humanities) (Vol. 31, Issue 9). https://digitalcommons.aaru.edu.jo/anujr_b/vol31/iss9/6/.

Fauzi, F., Erna, M., \& Linda, R. (2021). The effectiveness of collaborative learning through techniques on group investigation and Think Pair Share students' critical thinking ability on chemical equilibrium material. Journal of Educational Sciences, 5(1), 198-208. https://doi.org/10.31258/jes.5.1.p.198-208.

Fitriani, A., Baharuddin, M. R., \& Kayanti, J. (2019). Comparison of cooperative learning model Think Pair Share and Think Pair Square toward students' mathematical communication ability. ICONSS Proceeding Series, 202-208. https://doi.org/10.30605/iconss.22.

Ganatra, S., Doblanko, T., Rasmussen, K., Green, J., Kebbe, M., Amin, M., \& Perez, A. (2020). Perceived effectiveness and applicability of Think-Pair-Share Including Storytelling (TPS-S) to enhance clinical learning. Teaching and Learning in Medicine, 1-12. https://doi.org/10.1080/10401334.2020.1811094.

Hamdan, R. K. A. (2017). The effect of (Think-Pair-Share) strategy on the achievement of third grade student in sciences in the educational district of irbid. Journal of Education and Practice, 8(9), 88-95. http://eric.ed.gov/?ti=Active+Learning.

Handoko, P. (2013). Upaya meningkatkan hasil belajar matematika siswa melalui model pembelajaran kooperatif tipe (Team Games Tournament) TGT pada mata pelajaran matematka di kelas V SD Negeri No. 056616 Pasar XII Tahun Ajaran 2012/2013. Universitas Negeri Medan. 
Hikmah, M., Anwar, Y., \& Riyanto. (2018). Penerapan model pembelajaran Team Games Tournament (TGT) terhadap motivasi dan hasil belajar peserta didik pada materi dunia hewan kelas X di SMA Unggul Negeri 8 Palembang. In Jurnal Pembelajaran Biologi (Vol. 5, Issue 1). https://doi.org/10.36706/fpbio.v5i1.7049.

Intan, I. P., \& Wahyuni, D. S. (2014). Improving the students' participation in speaking by using Teams Games Tournament. English Education Journal, 7(1), 18-24. https://doi.org/10.20961/eed.v7i1.35828.

Kusmiati, Chamdani, M., \& Suryandari, K. C. (2016). Pembelajaran kooperatif tipe ThinkPair-Share untuk meningkatkan hasil belajar matematika siswa kelas II SDN Rahayu tahun ajaran 2012/2013. Kalam Cendekia PGSD Kebumen, 4(1), 1-7. https://jurnal.fkip.uns.ac.id/index.php/pgsdkebumen/article/view/2053/.

Mugas, I. (2014). Penerapan model pembelajaran TGT (Team Games Tournament) dengan media powerpoint untuk meningkatkan kualitas pembelajaran IPS pada siswa kelas VC SD Islam Hidayatullah Kota Semarang [Universitas Negeri Semarang]. http://lib.unnes.ac.id/20102/.

Nasution, Y. S., \& Surya, E. (2017). Application of TPS type cooperative learning in improving students' mathematics learning outcomes. International Journal of Sciences: Basic and Applied Research, 34(1), 116-125. http://gssrr.org/index.php?journal=JournalOfBasicAndApplied.

Prahl, K. (2017). Best practices for the Think-Pair-Share Active-Learning Technique Kristine Prahl. American Biology Teacher, 79(1), 3-8. https://doi.org/10.1525/abt.2017.79.1.3.

Raba, A. A. A. (2017). The influence of Think-Pair-Share (TPS) on improving students' oral communication skills in EFL classrooms. Creative Education, 8(1), 12-23. https://doi.org/10.4236/ce.2017.81002.

Salam, R. (2014). Efektivitas Penggunaan model pembelajaran kooperatif tipe Think Pair Share (TPS) untuk meningkatkan kepercayaan diri dan komunikasi matematis siswa SMAN 9 Makassar. In Jurnal Nalar Pendidikan (Vol. 2, Issue 2). https://doi.org/10.26858/jnp.v2i2.1975.

Sinaga, L. S., \& Rajagukguk, W. (2018). Perbedaan hasil belajar siswa yang diajar dengan menggunakan model pembelajaran kooperatif tipe Teams Games Tournament dan tipe Think Pair Share. Jurnal Inspiratif, 4(2), 26-36. https://doi.org/10.24114/jpmi.v4i2.12766.

Sumekto, D. R. (2018). Investigating the influence of Think-Pair-Share approach toward students' reading achievement. Lingua Cultura, 12(2), 195-202. https://doi.org/10.21512/lc.v12i2.4011. 